BEATA GROCHALA*

\title{
IGRZYSKA OLIMPIJSKIE W NAGŁÓWKACH ZAMKNIĘTE
}

\section{O NAGŁÓWKU I JEGO FUNKCJACH}

Urszula Żydek-Bednarczuk zauważa, że „każdy tekst ma swoje pozycje strategiczne, to znaczy takie, na których zwiększa się uwaga odbiorcy, jednocześnie pozycje te sa celowo konstruowane przez nadawców"'. W przypadku artykułów prasowych za taki element strategiczny uznać należy nagłówek. Jest to inicjalny składnik tekstu, który, jak pisze Maria Wojtak, ,funkcjonuje jako metatekst, czyli tekst o tekście, może też być ujmowany jako paratekst, czyli ważny składnik otoczenia tekstu właściwego, służący jego prezentacji"”.

Klasyczna definicja nagłówka Walerego Pisarka, zawarta w rozprawie Poznać prasę po nagłówkach! mówi, że jest to „wydrukowany tytut (wraz z ewentualnymi nadtytułami i podtytułami) wypowiedzi, działu lub rubryki w czasopiśmie"”. Podobnie definiują nagłówek autorzy Encyklopedii wiedzy o prasie: „,nagłówek wypowiedzi prasowej to uksztaltowany graficznie tytut (główny) wraz z ewentualnymi nadtytułami i podtytułami”", a także Słownika terminologii medialnej: „początkowy element materiału dziennikarskiego (wypowiedzi dziennikarskiej) składajacy się z tytulu oraz podtytulu lub nadtytutu"s.

Przytoczone definicje jednoznacznie określają zadania nagłówka: ma informować o treści wypowiedzi, zachęcać potencjalnego czytelnika do przeczytania artykułu, uatrakcyjniać kolumnę od strony graficznej.

\footnotetext{
* Dr hab. Beata Grochala - Katedra Lingwistyki Stosowanej i Kulturowej Uniwersytetu Łódzkiego, e-mail: beatag@uni.lodz.pl.

${ }^{1}$ U. Żydek-Bednarczuk, Wprowadzenie do lingwistycznej analizy tekstu, Kraków 2005, s. 171.

2 M. Wojtak, Gatunki prasowe, Lublin 2004, s. 21.

3 W. Pisarek, Poznać prasę po nagłówkach!, Kraków 1967, s.4.

${ }^{4}$ Encyklopedia wiedzy o prasie, red. J. Maślanka, Wrocław 1976, s.150.

${ }^{5}$ Stownik terminologii medialnej, red. W. Pisarek, Kraków 2006.
} 
Stanisław Gajda zalicza tytuły tekstów, w tym nagłówki, do nazw własnych, a dokładnie do ideonimów ${ }^{6}$, czyli nazw obiektów niematerialnych, indywidualnych niezależnie od nakładu i liczby wydań. Badacz wyróżnia również trzy funkcje tytułu: nominatywną, deskryptywną i pragmatyczną7. Funkcja nominatywna, czyli identyfikująco-indywidualizująca polega na nazywaniu indywidualnego tekstu. Funkcja deskryptywna albo inaczej charakteryzująco-informacyjna łączy się z przekazywaniem informacji o tekście, zaś funkcja pragmatyczna obejmuje oddziaływanie na odbiorcę i wiąże się z zagadnieniem ekspresywności nagłówków.

Zdaniem Stanisława Beresia nagłówek pełni rolę tzw. „etykietki” tekstu, niejednokrotnie decydując o tym, czy tekst zostanie przeczytany czy też pominięty ${ }^{8}$. Edyta Pałuszyńska zwraca zaś uwagę na fakt, że od tytułu tekstu prasowego wymaga się ,funkcjonalności i integralności z całościq wypowiedzi. Może więc streszczać najważniejsza informację, określać temat artykułu, wskazywać główna okoliczność, nastrój”"

Wspomniane funkcje nagłówków stały się przyczynkiem do zajęcia się problematyką olimpijską ,zamkniętą” w tych krótkich tekstach. Skoro bowiem, jak pisze W. Pisarek, tytuł ,jest oknem wystawowym wypowiedzi wydrukowanej: informuje o towarze $i$ zachęca do jego nabycia"10, to ich analiza diachroniczna powinna pokazać, jak zmienia się postrzeganie igrzysk. Trzeba jednak pamiętać, że jest to postrzeganie subiektywne, patrzymy na igrzyska oczyma nadawcy medialnego, który decyduje o wadze danych informacji i kształtuje świadomość odbiorcy. „Czytelnicy natomiast trwale zapamiętują najczęściej jedynie tytuły tekstów dziennikarskich $i$ to one często sa sygnatem wskazujacym wagę danego wydarzenia" "1.

Wojciech Kajtoch twierdzi, że na podstawie nagłówków można dokonać rekonstrukcji tekstowego obrazu świata, czyli „swoistej, dokonanej w konkretnym tekście - lub w zespole tekstów - realizacji językowego obrazu świata (...), a więc zbioru prawidłowości wyniktych z faktu preferowania w danym tekście lub zespole tekstów określonych konstrukcji fleksyjnych, słowotwórczych, składniowych, a przede wszystkim określonego słownictwa"12. I taki jest właśnie cel niniejszego artykułu - ukazanie tekstowego obrazu igrzysk z lat 1988-2016 zawartego w nagłówkach prasowych.

${ }^{6}$ S. Gajda, O tytulach tekstów. Wprowadzenie do problematyki, „Zeszyty Naukowe WSP w Opolu, Filologia Polska", t. XXIV, 1985, s.142.

7 S. Gajda, Społeczne determinacje nazw własnych tekstów (tytułów), „Socjolingwistyka”, nr 6, 1987, s.83-85.

${ }^{8}$ S. Bereś, Problematyka komunikatywności i metaforyczności nagłówków prasowych na przykładzie ,Stowa Polskiego”, „Wrocławski Rocznik Prasoznawczy”, 1974, s.92.

${ }^{9}$ E. Pałuszyńska, Nagłówki w „Gazecie Wyborczej” (ekspresywna leksyka, frazematyka, metaforyka), Łódź 2006, 9.

${ }_{10}$ W. Pisarek, Nowa retoryka dziennikarska, Kraków 2002, s. 163.

${ }_{11}$ M. Ślawska, Tytut - najmniejszy tekst prasowy, „Rocznik Prasoznawczy”, t. II, 2008, s. 119.

${ }_{12}$ W. Kajtoch, Językowy obraz świata i czlowieka w prasie młodzieżowej i alternatywnej, Kraków 2008, t. 1, s. 14. 


\section{CHARAKTERYSTYKA MATERIAŁU BADAWCZEGO}

Lata 1988-2016 to okres bardzo dużych i szybkich zmian na rynku medialnym, w tym prasowym. Liczba pojawiających się tytułów dzienników i czasopism wzrastała z każdym rokiem i przeanalizowanie wszystkich wydawnictw prasowych z tego okresu przekraczałoby znacznie zakres tego artykułu. Dlatego zdecydowałam się na analizę trzech tytułów prasowych - dwóch dzienników ogólnopolskich („Gazety Wyborczej” oraz „Super Expressu”) i jednej gazety sportowej („Przeglądu Sportowego”). Wybór podyktowany był kilkoma powodami. Po pierwsze, zależało mi na tytułach prasowych zakorzenionych na polskim rynku medialnym, wysokonakładowych, o dużym zasięgu oddziaływania. „Przegląd Sportowy" jawi się w tym gronie jako nestor, ukazuje się bowiem od 1921 roku i trudno byłoby znaleźć gazetę ogólnotematyczną o zasięgu krajowym mogącą poszczycić się tyloma latami edycji. „Gazeta Wyborcza” i „Super Express” należą do pierwszych gazet w swoich profilach ukazujących się nieprzerwanie od czasów wydania pierwszego numeru (odpowiednio 1989 i 1991 rok). „Gazeta Wyborcza” to dziennik o profilu społeczno-politycznym, natomiast „Super Express” - sensacyjno-rozrywkowym. Ta różnorodność tematyczna wspomnianych gazet była drugim powodem wyboru właśnie tych periodyków. Założono bowiem, że ze względu na swą odmienność dzienniki te będą z różnych perspektyw opisywać i oceniać igrzyska. Początkowe plany badawcze zakładały analizę wszystkich numerów olimpijskich, jednak ze względu na obszerność materiału zdecydowano się na jego ograniczenie. Dlatego przeprowadzone analizy uznać należy za badania pilotażowe. Wprowadzono dwa kryteria ograniczające materiał. Pierwsze, tematyczne - analizowano jedynie nagłówki dotyczące występów reprezentantów Polski. Drugie, czasowe - zbadano tytuły dotyczące wybranych igrzysk olimpijskich zimowych i letnich.

Ze względu na dużą dynamikę zmian po roku 1989, analizę rozpoczęto od igrzysk 1988 roku w Calgary oraz w Seulu, ale tu ze wspomnianych gazet dostępny był jedynie „Przegląd Sportowy”, zakończono zaś na igrzyskach w Rio de Janeiro w 2016 roku. Poza tym uwzględniono pierwsze ,pełne”, czyli opisane we wszystkich trzech gazetach igrzyskach, a mianowicie Albertville 1992, a także zimowe igrzyska w Turynie 2006 oraz letnie w Pekinie 2008. Wykaz igrzysk olimpijskich objętych badaniem przedstawia się zatem następująco:

- XV Zimowe Igrzyska Olimpijskie w Calgary;

- XXIV Letnie Igrzyska Olimpijskie w Seulu;

- XVI Zimowe Igrzyska Olimpijskie w Albertville;

- XX Zimowe Igrzyska Olimpijskie w Turynie;

- XXIX Letnie Igrzyska Olimpijskie w Pekinie;

- XXXI Letnie Igrzyska Olimpijskie w Rio de Janeiro. 
Podczas badania skoncentrowano się na analizie porównawczej dotyczącej z jednej strony obecności/ braku pewnych tematów w poszczególnych dziennikach, z drugiej zaś na komparatystycznym opisie obrazu igrzysk zawartego w nagłówkach.

\section{CALGARY 1988}

Na igrzyska do Kanady pojechało 33 reprezentantów Polski. Nie zdobyliśmy żadnego medalu, a najwyższą lokatę, piątą, zdobył Grzegorz Filipowski w jeździe figurowej na lodzie oraz Elwira Ryś-Ferens w łyżwiarstwie szybkim na $3000 \mathrm{~m}$.

Rok 1988 to czas mediów cenzurowanych, zależnych od Komitetu Centralnego PZPR nawet w zakresie sportu. Nagłówki „Przeglądu Sportowego” miały zdecydowanie charakter informacyjny i koncentrowały się na kilku dyscyplinach:

- hokeju (Remis po 60 latach/Polska-Szwecja 1:1/; Smutne kino nocne z udziałem hokeistów /przegrana 1:4 ze Szwajcarią/; Wszystko jest możliwe, choć nieprawdopodobne /o skandalu dopingowym z udziałem polskiego hokeisty/);

- łyżwiarstwie figurowym (Grzegorz zaczą jak w Cincinnati /7. miejsce po programie obowiązkowym Grzegorza Filipowskiego/ Grzegorz nie zawiódt /5. miejsce Grzegorza Filipowskiego/);

- łyżwiarstwie szybkim (Kłopoty na małym tuku /o występie panczenistów w eliminacjach/; Blair jak rakieta, Polki daleko /słaby występ łyżwiarek na 500 m/; Dziewczyna bez medalu /E. Ryś-Ferens zajęła dopiero 5. miejsce na 5000 m/);

- skokach narciarskich (Ten wielki Matti! Piotr Fijas dziesiaty; Teatr jednego aktora /M. Nykaenen wygrał turniej skoków, P. Fijas zajął 10. miejsce/).

\section{SEUL 1988}

Letnie igrzyska olimpijskie są dla Polaków zazwyczaj większym powodem do radości, co wynika zarówno z większej liczby reprezentantów, jak i lepszych rezultatów. W Seulu byliśmy reprezentowani w 19 dyscyplinach, a zdobyliśmy 16 medali, w tym dwa złote. To ogromna dysproporcja między zimowymi i letnimi występami Polaków widoczna jest w nagłówkach „Przeglądu Sportowego”. Jest ich zdecydowanie więcej, dotyczą większości występów Polaków, a przede wszystkim są ciekawsze. Zaprezentuję jedynie te, które dotyczą zdobytych medali srebrnych i złotych:

- Znowu mamy wspaniatych kolarzy/srebro w drużynowym wyścigu na $100 \mathrm{~km} /$;

- Chciałbym zamienić srebro na złoto /Andrzej Gołąb o swoim srebrnym medalu w zapasach do $48 \mathrm{~kg} /$;

- Andrzej Wroński przypomniat światu Mazurka Dąbrowskiego /złoty medal polskiego zapaśnika/;

- Brawo Janusz! /Janusz Olech wicemistrzem olimpijskim w szabli/; 
- Pawłowski pokazał, jak się wygrywa z mistrzem świata /Janusz Pawłowski zdobył srebrny medal w judo, a w półfinale pokonał mistrza świata/;

- Waldemar Legień królem rzutów w hali Changchung /o złotym medalu W. Legienia w zapasach/;

- Marek Łbik i Marek Dopierała - podwójni medaliści /po zdobyciu brązu na 100 metrów dwójka kajakarzy zdobyła srebro na 500 metrów w kanadyjkach/.

Warto odnotować, że wspomniana wcześniej ingerencja partyjna w prezentowane treści widoczna jest choćby w opublikowaniu na łamach „Przeglądu Sportowego" depeszy gratulacyjnych, które pierwszy sekretarz PZPR, Wojciech Jaruzelski, przesłał złotym medalistom:

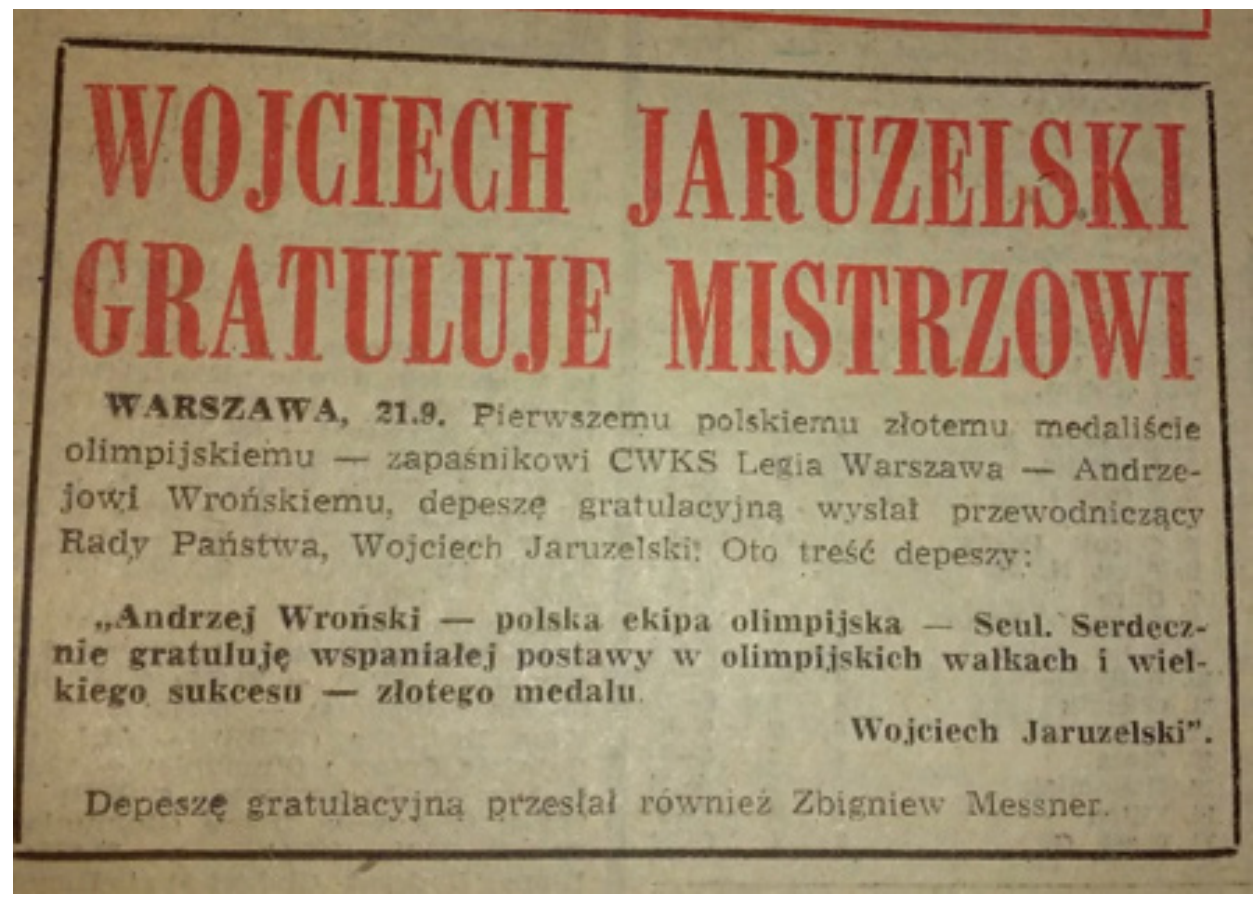

ALBERTVILLE 1992

Reprezentacja Polski na igrzyska w Albertville liczyła 53 osoby (w tym reprezentacja hokejowa). Najwyższe miejsce, ósme, zdobył Stanisław Ustupski w kombinacji norweskiej. Nie były to zatem, jak zazwyczaj w przypadku zimowych igrzysk, udane zawody dla Polaków. Odzwierciedlenie tego widać w nagłówkach. Igrzyska nie należały do najpopularniejszych tematów, nawet w sprofilowanej gazecie, „Przeglądzie Sportowym”. Najwięcej miejsca poświęcono występowi drużyny hokejowej, która wygrała zaledwie jeden mecz podczas całego turnieju. Ciekawe, 
że zarówno „Gazeta Wyborcza”, jak i „Super Express” poświęciły osobne teksty występowi Grzegorza Filipowskiego, natomiast „Przegląd Sportowy” - nie. Warto zatrzymać się przy jednym z nagłówków „Przeglądu Sportowego” - Jest srebrny medal - rozbudza on nadzieję w czytelnikach na oczekiwany dobry występ Polaka, a tymczasem okazuje się, że chodzi o zawody filatelistyczne rozgrywane przy okazji igrzysk. Tytuł ten pokazuje irytację, zniecierpliwienie i potrzebę jakiegokolwiek sukcesu Polaków.

\begin{tabular}{|c|c|c|c|}
\hline WYDARZENIE & Przegląd Sportowy & Gazeta Wyborcza & Super Express \\
\hline \multicolumn{4}{|c|}{ HOKEJ } \\
\hline $\begin{array}{l}\text { Hokeiście przegrali } \\
\text { z mistrzami świata, } \\
\text { Szwecją, } 2: 7\end{array}$ & $\begin{array}{l}\text { W premierze bez zęba, } \\
\text { ale nie najgorzej }\end{array}$ & ---- & $\begin{array}{l}\text { Z mistrzami świata nie } \\
\text { było kompromitacji }\end{array}$ \\
\hline $\begin{array}{l}\text { Hokeiści przegrali } \\
\text { z Finlandią 1:9 }\end{array}$ & Po szkolnych błędach & Porażka 1:9 z Finami & ------------------------ \\
\hline $\begin{array}{c}\text { Hokej Polska - USA } \\
0: 3\end{array}$ & Wreszcie powalczyli & $\begin{array}{l}\text { Trzecia porażka } \\
\text { Polaków }\end{array}$ & ---------- \\
\hline $\begin{array}{c}\text { Hokej Polska-Niemcy } \\
\text { 0:4; najlepszym za- } \\
\text { wodnikiem Polski był } \\
\text { bramkarz - Mariusz } \\
\text { Kieca }\end{array}$ & $\begin{array}{c}\text { Panu Bogu i Helmu- } \\
\text { towi }\end{array}$ & $0: 4$ z Niemcami & $\begin{array}{c}\text { Gdyby wszyscy tak jak } \\
\text { Kieca }\end{array}$ \\
\hline $\begin{array}{l}\text { Przed meczem Polska- } \\
\text {-Włochy w hokeja }\end{array}$ & 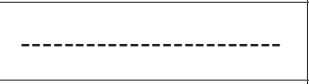 & $\begin{array}{l}\text { Dziś z Włochami } \\
\text { o uratowanie twarzy }\end{array}$ & ------------------------ \\
\hline $\begin{array}{l}\text { Hokej Polska-Włochy } \\
\text { 4:1 }\end{array}$ & $\begin{array}{c}11 \text { miejsce hokeistów } \\
\text { po wygranej z Wto- } \\
\text { chami }\end{array}$ & $\begin{array}{l}\text { Na pożegnanie zwy- } \\
\text { cięstwo }\end{array}$ & $\begin{array}{l}\text { Tamten hokej byt } \\
\text { ciekawszy }\end{array}$ \\
\hline \multicolumn{4}{|c|}{ KOMBINACJA NORWESKA } \\
\hline $\begin{array}{l}\text { Stanisław Ustupski } \\
\text { zajął } 8 \text { miejsce w kom- } \\
\text { binacji norweskiej }\end{array}$ & $\begin{array}{c}\text { Ustupski walczyt do } \\
\text { upadtego }\end{array}$ & 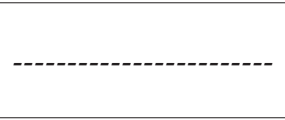 & --- \\
\hline \multicolumn{4}{|c|}{ BIEGI NARCIARSKIE } \\
\hline $\begin{array}{c}\text { Słaby występ Polek na } \\
15 \text { km klasykiem }\end{array}$ & $\begin{array}{c}\text { Prognozy swoje, życie } \\
\text { swoje }\end{array}$ & & \\
\hline $\begin{array}{l}\text { Polki nie miały dobrze } \\
\text { nasmarowanych nart } \\
\text { w biegu na } 5 \mathrm{~km}\end{array}$ & Nos sprzyjat lepszym & ---------------- & ------------- \\
\hline \multicolumn{4}{|c|}{ ŁYŻWIARSTWO FIGUROWE } \\
\hline $\begin{array}{c}\text { Po pierwszej kon- } \\
\text { kurencji Grzegorz } \\
\text { Filipowski zajmuje } \\
13 \text { miejsce w turnieju } \\
\text { solistów w jeździe } \\
\text { figurowej }\end{array}$ & & Filipowski 13. & $\begin{array}{c}\text { W Lozannie nie poka- } \\
\text { zatem... }\end{array}$ \\
\hline
\end{tabular}




\begin{tabular}{|c|c|c|c|}
\hline WYDARZENIE & Przegląd Sportowy & Gazeta Wyborcza & Super Express \\
\hline $\begin{array}{l}\text { G. Filipowski zajął } 11 \\
\text { miejsce }\end{array}$ & ------------------------- & Grzegorz, co dalej? & $\begin{array}{c}\text { Elegancki Pietrenko } \\
\text { wreszcie ze zlotem. } \\
\text { Jeszcze o kotletach } \\
\text { Grzegorza }\end{array}$ \\
\hline \multicolumn{4}{|c|}{ VARIA } \\
\hline $\begin{array}{l}\text { Roman Babut zdobył } \\
\text { srebrny medal za } \\
\text { kolekcję znaczków } \\
\text { olimpijskich }\end{array}$ & Jest srebrny medal! & ------------------------ & \\
\hline $\begin{array}{c}\text { Podsumowanie } \\
\text { występów Polaków na } \\
\text { igrzyskach }\end{array}$ & $\begin{array}{l}\text { To koniec, ale nie } \\
\text { ptaczcie. Następne } \\
\text { igrzyska już za dwa } \\
\text { lata }\end{array}$ & & \\
\hline $\begin{array}{l}\text { W ceremonii zamknię- } \\
\text { cia Polskę reprezento- } \\
\text { wał attache olimpijski, } \\
\text { Andrzej Bachleda }\end{array}$ & $\begin{array}{c}\text { Andrzej Bachleda } \\
\text { wyglądat godnie }\end{array}$ & & \\
\hline
\end{tabular}

TURYN 2006

Tym razem reprezentacja Polski liczyła 46 sportowców, którzy zdobyli dwa medale - srebrny Tomasz Sikora w biathlonie i brązowy Justyna Kowalczyk w biegu na 30 $\mathrm{km}$. Igrzyska trudno zatem zaliczyć do udanych, zwłaszcza jeśli chodzi o występy Adama Małysza (na poprzednich igrzyskach w Salt Lake City A. Małysz zdobył srebrny i brązowy medal, dlatego spodziewano się medalu także w Turynie).

\begin{tabular}{|c|c|c|c|}
\hline WYDARZENIE & Przegląd Sportowy & Gazeta Wyborcza & Super Express \\
\hline \multicolumn{4}{|c|}{ SKOKI NARCIARSKIE } \\
\hline \multirow{3}{*}{$\begin{array}{c}\text { 7. miejsce Adama } \\
\text { Małysza na normalnej } \\
\text { skoczni }\end{array}$} & Nie doleciał... & Nie dla nas medale & Może być tylko lepiej \\
\hline & Będzie śnit... & Matysz zrobit, co mógł & \\
\hline & $\begin{array}{l}\text { Nasz mistrz mówi: } \\
\text { walczę dalej }\end{array}$ & $\begin{array}{l}\text { Kurcze, jakbym tak } \\
\text { skoczyt metr dalej }\end{array}$ & \\
\hline \multirow[t]{3}{*}{$\begin{array}{l}\text { 14. miejsce A. Małysza } \\
\text { na dużej skoczni }\end{array}$} & Bez energii & $\begin{array}{c}\text { Matysz: Moja wielka } \\
\text { porażka }\end{array}$ & Matysz dopiero 14. \\
\hline & $\begin{array}{l}\text { Lata chaosu zamiast } \\
\text { szkolenia }\end{array}$ & Kuttin: Tajner miesza & $\begin{array}{c}\text { Wypalit się, bo start } \\
\text { nie wypalił }\end{array}$ \\
\hline & & $\begin{array}{l}\text { Tajner: Nie byto } \\
\text { najlepiej }\end{array}$ & $\begin{array}{c}\text { Z Matysza zrobit } \\
\text { cieniasa /o trenerze H. } \\
\text { Kuttinie/ }\end{array}$ \\
\hline \multicolumn{4}{|c|}{ BIEGI NARCIARSKIE } \\
\hline
\end{tabular}




\begin{tabular}{|c|c|c|c|}
\hline WYDARZENIE & Przegląd Sportowy & Gazeta Wyborcza & Super Express \\
\hline \multirow[t]{2}{*}{$\begin{array}{c}\text { 8. miejsce Justyny } \\
\text { Kowalczyk na } 15 \mathrm{~km} \\
\end{array}$} & Polski fenomen & Ale jestem wypruta & Moc jest $z$ niq \\
\hline & & $\begin{array}{c}\text { W czwartek idę na } \\
\text { catość }\end{array}$ & $\begin{array}{l}\text { To będzie orzet } \\
\text { w spódnicy }\end{array}$ \\
\hline \multirow[t]{3}{*}{$\begin{array}{l}\text { J. Kowalczyk zemdlała } \\
\text { przed metą sprintu }\end{array}$} & Upadek nadziei & $\begin{array}{c}\text { Justyna zemdlała } \\
\text { przed meta }\end{array}$ & Zgasto jej światto \\
\hline & Dramat Polki & $\begin{array}{l}\text { Stres zjadt moje } \\
\text { kalorie }\end{array}$ & $\begin{array}{l}\text { Batam sie, czy serce } \\
\text { mamy to wytrzyma }\end{array}$ \\
\hline & Śniadanko & & \\
\hline \multirow[t]{4}{*}{$\begin{array}{l}\text { Brązowy medal J. Ko- } \\
\text { walczyk na } 30 \mathrm{~km}\end{array}$} & Atak na medal & Justyna na medal & Jak Feniks z popiołów \\
\hline & Królowa śniegu & $\begin{array}{l}\text { Fajnie było /rozmowa } \\
\text { z Justyną Kowalczyk/ }\end{array}$ & Mamy medal \\
\hline & $\begin{array}{c}\text { Ona kiedyś będzie } \\
\text { złota }\end{array}$ & & \\
\hline & Wulkan energii & $\begin{array}{c}\text { Stoje z boku } \\
\text { /rozmowa z trenerem } \\
\text { A. Wierietielnym/ }\end{array}$ & \\
\hline \multicolumn{4}{|c|}{ BIATHLON } \\
\hline \multirow[t]{2}{*}{$\begin{array}{l}\text { 21. miejsce Tomasza } \\
\text { Sikory na } 20 \mathrm{~km}\end{array}$} & $\begin{array}{c}\text { We wtorek będzie } \\
\text { ulubiony sprint }\end{array}$ & $\begin{array}{c}\text { Trzy pudta zamiast } \\
\text { podium }\end{array}$ & Oczko Sikory \\
\hline & & Jestem zawiedziony & \\
\hline \multirow[t]{4}{*}{$\begin{array}{l}\text { Srebrny medal T. } \\
\text { Sikory }\end{array}$} & Trafit srebro & Srebro Sikory & $\begin{array}{c}\text { Dziękowat Bogu za } \\
\text { strzelanie }\end{array}$ \\
\hline & Celny i szybki & Dzięki Bogu & $\begin{array}{l}\text { Milimetry dzielity go } \\
\text { od zlota }\end{array}$ \\
\hline & $\begin{array}{l}\text { Medal byt zaplano- } \\
\text { wany }\end{array}$ & $\begin{array}{l}\text { Najpiękniejszy dzień } \\
\text { Tomka }\end{array}$ & $\begin{array}{c}\text { Ile nerwów żech } \\
\text { stracita, to nie wie... / } \\
\text { rozmowa z matką T. } \\
\text { Sikory/ }\end{array}$ \\
\hline & $\begin{array}{l}\text { Nie widziat nic } \\
\text { dookota }\end{array}$ & & \\
\hline
\end{tabular}

Na XXIX letnie igrzyska pojechało 263 sportowców z Polski, którzy reprezentowali 22 dyscypliny. Zdobyliśmy 11 medali:

- 4 złote (Tomasz Majewski - pchnięcie kulą, Leszek Blanik - gimnastyka sportowa, Konrad Wasilewski, Marek Kolbowicz, Michał Jeliński i Adam Korol wioślarstwo, Szymon Kołecki - podnoszenie ciężarów - medal po dyskwalifikacji Kazacha, Ilji Iljina za doping);

- 5 srebrnych (Aneta Konieczna i Beata Mikołajczyk - kajakarstwo, Piotr Małachowski - rzut dyskiem, Maja Włoszczowska - kolarstwo górskie, Tomasz Motyka, Adam Wiercioch, Radosław Zawrotniak i Robert Andrzejuk - szpada 
drużynowa, Łukasz Pawłowski, Bartłomiej Pawełczak, Miłosz Bernatajtys i Paweł Rańda - wioślarstwo);

- 2 brązowe (Agnieszka Wieszczek - zapasy, Marcin Dołęga - podnoszenie ciężarów - medal po dyskwalifikacji Rosjanina, Dmitrija Łapikowa za doping).

Jednocześnie to igrzyska zawiedzionych nadziei $\mathrm{w}$ grach zespołowych (siatkówce i piłce ręcznej)

\begin{tabular}{|c|c|c|c|}
\hline WYDARZENIE & Przegląd Sportowy & Gazeta Wyborcza & Super Express \\
\hline \multicolumn{4}{|c|}{ SIATKÓWKA } \\
\hline \multirow[t]{5}{*}{$\begin{array}{l}\text { Przygotowania siat- } \\
\text { karzy do pierwszego } \\
\text { meczu }\end{array}$} & Lekcja cierpliwości & $\begin{array}{c}\text { Silni, zdrowi, głodni } \\
\text { zwycięstw }\end{array}$ & \\
\hline & $\begin{array}{l}\text { Poranna gimnastyka } \\
\text { i natarczywe myśli } \\
\text { o debiucie }\end{array}$ & $\begin{array}{c}\text { Dwa kroki do ćwierć- } \\
\text { finatu }\end{array}$ & \\
\hline & Gramy, by wygrać & & \\
\hline & $\begin{array}{l}\text { Zwycięzca będzie } \\
\text { w ćwierćfinale }\end{array}$ & & \\
\hline & $\begin{array}{l}\text { Kaszubi w drużynie } \\
\text { trzymaja się razem }\end{array}$ & & \\
\hline \multirow[t]{2}{*}{ Polska-Niemcy 3:0 } & $\begin{array}{l}\text { Siatkarze o krok od } \\
\text { ćwierćfinatu }\end{array}$ & & Rozbroili Niemców \\
\hline & $\begin{array}{l}\text { Jedna noga w ćwierć- } \\
\text { finale }\end{array}$ & & \\
\hline \multirow[t]{2}{*}{ Polska-Egipt 3:0 } & Sa już w ćwierćfinale & Każdy punkt się liczyt & $\begin{array}{l}\text { Jesteśmy w ćwierćfi- } \\
\text { nale }\end{array}$ \\
\hline & $\begin{array}{c}\text { Chcemy zrewanżować } \\
\text { się Serbii }\end{array}$ & & \\
\hline \multirow[t]{2}{*}{ Polska-Serbia 3:1 } & Mamy wiare & & $\begin{array}{c}\text { Stodka zemsta za } \\
\text { serbskie kpiny }\end{array}$ \\
\hline & $\begin{array}{c}\text { W Rio byliśmy na } \\
\text { kolanach, teraz nie bo- } \\
\text { imy się nikogo, nawet } \\
\text { Brazylii }\end{array}$ & & \\
\hline \multirow[t]{2}{*}{ Polska-Brazylia 0:3 } & Bez strachu & $\begin{array}{l}\text { Brazylia, czyli nie- } \\
\text { szczęście }\end{array}$ & Nerwy i btędy \\
\hline & $\begin{array}{c}\text { Równa gra tylko } \\
\text { w pierwszym secie }\end{array}$ & & \\
\hline \multirow[t]{4}{*}{ Polska-Rosja 3:2 } & Podium jest blisko & Bitwa z Rosja wygrana & Rosja na kolanach \\
\hline & $\begin{array}{c}\text { Serwujemy coraz } \\
\text { lepiej }\end{array}$ & & \\
\hline & $\begin{array}{l}\text { Znam wage meczów } \\
\text { z Rosja /R. Lozano/ }\end{array}$ & & \\
\hline & Odparli rosyjski atak & & \\
\hline Polska-Włochy 2:3 & Dramat Polaków & $\begin{array}{c}\text { Nic się nie stało? Stato } \\
\text { się, stato }\end{array}$ & \\
\hline
\end{tabular}




\begin{tabular}{|c|c|c|c|}
\hline WYDARZENIE & Przegląd Sportowy & Gazeta Wyborcza & Super Express \\
\hline & $\begin{array}{c}\text { Jestem bardzo zły/S. } \\
\text { Świderski/ }\end{array}$ & $\begin{array}{c}\text { Wracamy z Pekinu } \\
\text { z podniesiona głowa } \\
\text { /R. Lozano/ }\end{array}$ & \\
\hline \multicolumn{4}{|c|}{ PIŁKA RĘCZNA } \\
\hline $\begin{array}{c}\text { Przygotowania } \\
\text { piłkarzy ręcznych do } \\
\text { pierwszego meczu }\end{array}$ & $\begin{array}{c}\text { Nie damy się nikomu } \\
\text { zbić }\end{array}$ & & \\
\hline Polska-Chiny 33:19 & $\begin{array}{c}\text { Chińczycy rozbili się } \\
\text { o polski mur }\end{array}$ & $\begin{array}{l}\text { Polski walec zmiażdzyt } \\
\text { Chiny }\end{array}$ & $\begin{array}{l}\text { Starli Chińczyków na } \\
\text { proch }\end{array}$ \\
\hline $\begin{array}{c}\text { Polska-Hiszpania } \\
\text { 29:30 }\end{array}$ & Czują się oszukani & $\begin{array}{c}\text { Przegrali, choć mogli } \\
\text { wygrać }\end{array}$ & Ale wpadka! \\
\hline Polska-Brazylia 28:25 & Wenta się zezłościt & $\begin{array}{c}\text { Ciężar spadt mi } \\
\text { z serca }\end{array}$ & Klaps $w$ tylek \\
\hline $\begin{array}{c}\text { Polska-Chorwacja } \\
\text { 27:24 }\end{array}$ & Pokonali mistrzów & & Grali jak w transie \\
\hline \multirow[t]{2}{*}{ Polska-Islandia 30:32 } & $\begin{array}{c}\text { Stracili szansę, na } \\
\text { która pracowali cztery } \\
\text { lata }\end{array}$ & $\begin{array}{c}\text { Islandzki lodowaty } \\
\text { prysznic }\end{array}$ & Leża i rycza \\
\hline & $\begin{array}{c}\text { Straszne, } \dot{z} e \text { to już } \\
\text { koniec }\end{array}$ & & \\
\hline \multicolumn{4}{|c|}{ GIMNASTYKA SPORTOWA } \\
\hline \multirow[t]{3}{*}{$\begin{array}{c}\text { Złoty medal Leszka } \\
\text { Blanika w gimnastyce } \\
\text { sportowej (ćwiczenia } \\
\text { na koniu) }\end{array}$} & Miat dzień konia & $\begin{array}{l}\text { Ztote salta Leszka } \\
\text { „Miodzia” Blanika }\end{array}$ & Złoty Leszek \\
\hline & Poczułem się spetniony & $\begin{array}{c}\text { Ciężko pracujesz - } \\
\text { masz medal }\end{array}$ & Ptakali ze szczęścia \\
\hline & & $\begin{array}{l}\text { Blanik odchodzi. Kto } \\
\text { skoczy superblanika? }\end{array}$ & Bóg dat mi medal \\
\hline \multicolumn{4}{|c|}{ WIOŚLARSTWO } \\
\hline \multirow[t]{4}{*}{$\begin{array}{l}\text { Złoty medal czwórki } \\
\text { podwójnej }\end{array}$} & Piękny koniec & & Ztote chtopaki \\
\hline & & & $\begin{array}{c}\text { Lepsi niż cztery lata } \\
\text { temu }\end{array}$ \\
\hline & & & $\begin{array}{l}\text { Prosiłam syna o Ma- } \\
\text { zurka }\end{array}$ \\
\hline & & & Mistrz mimo choroby \\
\hline \multicolumn{4}{|c|}{ TENIS ZIEMNY } \\
\hline $\begin{array}{l}\text { Kontuzja Agnieszki } \\
\text { Radwańskiej }\end{array}$ & & & $\begin{array}{l}\text { Dla Isi palec to teraz } \\
\text { największy wróg }\end{array}$ \\
\hline
\end{tabular}

\section{RIO DE JANEIRO 2016}

Na ostatnich igrzyskach olimpijskich reprezentacja Polski liczyła 240 zawodników, którzy zdobyli 11 medali: 
- 2 złote (Anita Włodarczyk - rzut młotem, Magdalena Fularczyk-Kozłowska i Natalia Madaj - wioślarstwo);

- 3 srebrne (Piotr Małachowski - rzut dyskiem, Maja Włoszczowska - kolarstwo górskie, Marta Walczykiewicz - kajakarstwo);

- 6 brązowych (Rafał Majka - kolarstwo szosowe, Monika Michalik - zapasy, Oktawia Nowacka - pięciobój, Wojciech Nowick - rzut młotem, Karolina Naja i Beata Mikołajczyk - kajakarstwo, Maria Springwald, Joanna Leszczyńska, Agnieszka Kobus i Monika Ciaciuch - wioślarstwo).

Największym rozczarowaniem igrzysk była afera dopingowa sztangistów, braci Adriana i Tomasza Zielińskich, którzy zostali zdyskwalifikowani za stosowanie niedozwolonych środków farmakologicznych.

\begin{tabular}{|c|c|c|c|}
\hline WYDARZENIE & Przegląd Sportowy & Gazeta Wyborcza & Super Express \\
\hline \multicolumn{4}{|c|}{ PODNOSZENIE CIĘŻARÓW } \\
\hline \multirow[t]{7}{*}{$\begin{array}{c}\text { Afera dopingowa braci } \\
\text { Zielińskich }\end{array}$} & $\begin{array}{l}\text { Ktoś podtożyt mi } \\
\text { świnię }\end{array}$ & $\begin{array}{c}\text { Wstyd ciężki jak } \\
\text { sztanga }\end{array}$ & Koks Brothers? \\
\hline & Dymisja Koteckiego & $\begin{array}{l}\text { Zieliński wyleciat. Ko- } \\
\text { tecki zrezygnowat }\end{array}$ & $\begin{array}{l}\text { Nie mogę uwierzyć, } \\
\text { ze moi synowie sa na } \\
\text { koksie }\end{array}$ \\
\hline & Braterski wstyd? & $\begin{array}{c}\text { Odsunać doping od } \\
\text { igrzysk }\end{array}$ & Koks Brothers! \\
\hline & $\begin{array}{l}\text { Dopingowy smród } \\
\text { wokót mistrza }\end{array}$ & $\begin{array}{c}\text { NIE dla sztangistów } \\
\text { w Rio }\end{array}$ & \\
\hline & $\begin{array}{c}\text { Adrian Zieliński tė̇ na } \\
\text { dopingu! }\end{array}$ & $\begin{array}{c}\text { Kto wyczyści brudna } \\
\text { sitownię? }\end{array}$ & \\
\hline & Igrzyska wstydu & & \\
\hline & $\begin{array}{l}\text { Nie mam wyrzutów } \\
\text { sumienia }\end{array}$ & & \\
\hline \multicolumn{4}{|c|}{ WIOŚLARSTWO } \\
\hline \multirow[t]{4}{*}{$\begin{array}{c}\text { Złoto dwójki wioślar- } \\
\text { skiej }\end{array}$} & Nareszcie złoto! & $\begin{array}{l}\text { My, dwójka idealna, } \\
\text { osada ze złota }\end{array}$ & Ztoto. Panie na medal \\
\hline & $\begin{array}{c}\text { Dziewczyny poptynęty } \\
\text { jak nigdy }\end{array}$ & & $\begin{array}{l}\text { Zazdrościmy wioślar- } \\
\text { kom medali! }\end{array}$ \\
\hline & $\begin{array}{c}\text { Chrystus nad nami } \\
\text { czuwat }\end{array}$ & & Ztote drobne kobietki! \\
\hline & $\begin{array}{c}\text { Tak świętowali bliscy } \\
\text { mistrzyń }\end{array}$ & & $\begin{array}{c}\text { Dziewczyny na medal } \\
\text { wrócity do Polski }\end{array}$ \\
\hline \multicolumn{4}{|c|}{ RZUT MŁOTEM } \\
\hline \multirow[t]{4}{*}{$\begin{array}{l}\text { Złoto Anity Włodar- } \\
\text { czyk }\end{array}$} & Rekordzistka & $\begin{array}{l}\text { Anita Włodarczyk: } \\
\text { miałam dzień konia }\end{array}$ & $\begin{array}{l}\text { Anita już pokazała } \\
\text { pazurki }\end{array}$ \\
\hline & $\begin{array}{c}\text { To byly najpiękniejsze } \\
\text { zawody w historii }\end{array}$ & ANITANISSIMA & $\begin{array}{c}\text { Anita będzie wniebo- } \\
\text { wzięta }\end{array}$ \\
\hline & $\begin{array}{c}\text { To byt mój konkurs } \\
\text { zycia! }\end{array}$ & & Zlota Anita \\
\hline & $\begin{array}{c}\text { Królowa Anita już } \\
\text { w domu }\end{array}$ & & Anita wniebowzięta \\
\hline
\end{tabular}




\begin{tabular}{|c|c|c|c|}
\hline WYDARZENIE & Przegląd Sportowy & Gazeta Wyborcza & Super Express \\
\hline \multicolumn{4}{|c|}{ RZUT DYSKIEM } \\
\hline \multirow[t]{2}{*}{$\begin{array}{l}\text { Srebro Piotra Mała- } \\
\text { chowskiego }\end{array}$} & Triumf byt tak blisko... & $\begin{array}{c}\text { Małachowski w środku } \\
\text { niemieckiej rodziny }\end{array}$ & $\begin{array}{l}\text { Ten medal jest dla } \\
\text { wszystkich Polaków, } \\
\text { niech się nie smuca }\end{array}$ \\
\hline & $\begin{array}{c}\text { Biało-czerwone } \\
\text { dramaty }\end{array}$ & & \\
\hline \multicolumn{4}{|c|}{ KOLARSTWO SZOSOWE } \\
\hline \multirow[t]{4}{*}{ Brąz Rafała Majki } & Ale jazda! & $\begin{array}{l}\text { Jak kolarze zaplano- } \\
\text { wali medal }\end{array}$ & $\begin{array}{l}\text { Rafal za medal dosta- } \\
\text { nie barszczyk z uszka- } \\
\text { mi /rozmowa z żoną R. } \\
\text { Majki/ }\end{array}$ \\
\hline & $\begin{array}{l}\text { Wielki Majka, wielka } \\
\text { drużyna. Na braz!! }\end{array}$ & Petna petarda $w$ dót & $\begin{array}{l}\text { Nie wywrócitem się, } \\
\text { bo się przeżegnatem }\end{array}$ \\
\hline & $\begin{array}{c}\text { Ciagle mam wielkie } \\
\text { marzenia }\end{array}$ & & Rafat III Wspaniaty \\
\hline & $\begin{array}{l}\text { Cztery dekady oczeki- } \\
\text { wania }\end{array}$ & & $\begin{array}{c}\text { Majka pojechat jak } \\
\text { mistrz }\end{array}$ \\
\hline
\end{tabular}

Analiza zaprezentowanych przykładów pokazuje pewne tendencje, które charakteryzują nagłówkową wizję igrzysk. Pierwsza kwestia to coraz bardziej zauważalna obecność sportu w prasie (i ogólnej w mediach). W przypadku igrzysk w Albertville (a i wcześniejszych w Calgary czy w Seulu) jednemu wydarzeniu odpowiada jeden nagłówek, a co za tym idzie jeden artykuł. Zatem czytelnik, który był zainteresowany danym wydarzeniem, po przeczytaniu owego tekstu powinien zdobyć wszystkie najważniejsze informacje. Zestawienie pokazuje, że tematyka olimpijska obecna byłą w większym stopniu w dzienniku specjalistycznym, w mniejszym zaś w dziennikach ogólnych. Co więcej, artykuły poświęcone igrzyskom w prasie ogólnotematycznej zaopatrzone były w tytuły pełniące przede wszystkim funkcję informacyjną (np. Filipowski 13., 0:4 z Niemcami, Z mistrzami świata nie byto kompromitacji, Tamten hokej byt ciekawszy). Tylko dwa $\mathrm{z}$ analizowanych tytułów (oba pochodzą z „Super Expressu”) nie realizują typowej funkcji nominatywnej - W Lozanie nie pokazatem... oraz Elegancki Pietrenko wreszcie ze złotem. Jeszcze o kotletach Grzegorza (tu pierwszy człon ma charakter informacyjny, drugi - perswazyjno-ekspresyjny). Niestety, te dwa nagłówki okazały się prorocze - w kolejnych latach ten typ tytułów zdecydowanie dominował zarówno w gazecie sportowej, jak i w dziennikach ogólnych. Towarzyszyło temu zwiększenie zainteresowania sportem, jeśli można tak zinterpretować zdecydowanie większą liczbę artykułów poświęconych rywalizacji olimpijskiej. Zmianę charakterystyczną, przejawiającą się bowiem w postaci publikowania kilku artykułów na ten sam temat, np. zdobycie przez Leszka Blanika złotego medalu w Pekinie zostało opisane w dwóch artykułach w „Przeglądzie Sportowym” (Miał dzień konia, Poczułem się spetniony), trzech w „Gazecie Wyborczej” (Złote salta Leszka ,Miodzia” Blanika, Ciężko pracujesz - masz medal, Blanik odchodzi. Kto skoczy superblanika?) i trzech 
w „Super Expressie” (Złoty Leszek, Płakali ze szczęścia, Bóg dał mi medal). Ciekawie na tym tle prezentują się badania W. Kajtocha ${ }^{13}$, który przeanalizował 1000 nagłówków „Super Expressu” i „Faktu”. Okazało się, że najczęściej zapowiadany przez nie temat dotyczy wydarzeń sportowych i sportowców (27\% w porównaniu z 19\% dla tematyki życia codziennego, które uplasowało się na drugim miejscu). Wyniki te pokazują, że sport przestał być tematem, którym interesują się wyłącznie kibice. Stał się trybikiem w maszynie show businessu.

Opisanym zmianom ilościowym towarzyszyły zmiany jakościowe, polegające przede wszystkim na obniżeniu poziomu nagłówków. Pokazują to najdobitniej tytuły z czasu igrzysk w Rio de Janeiro. Ogólna tendencja, właściwa początkowo tylko dla „Super Expressu”, tj. zamieszczanie wywiadów, czy może raczej krótkich rozmów z rodzinami sportowców, pojawiła się już nawet na łamach „Przeglądu Sportowego" (Tak świętowali bliscy mistrzyń). Fakt, że prasa tabloidalna sprowadza igrzyska do warstwy kulinarnej (Rafat za medal dostanie barszczyk z uszkami), kosmetycznej (Anita juz pokazała pazurki - tekst o manicure Anity Włodarczyk), czy sensacji medycznych (Dla Isi palec to teraz największy wróg) nie dziwi, ponieważ takie prezentowanie wydarzeń wpisuje się w konwencję gazety. Dziwi natomiast przejmowanie takiej konwencji przez gazetę sportową i ogólnotematyczną. I choć nie znajdziemy w nich wymienionych obszarów tematycznych w połączeniu ze sportem, to jednak uderza pogoń za czytelnikiem przejawiająca się m.in. w sensacyjnym charakterze nagłówków (np. Nic się nie stało? Stało się, stało; Straszne, że to juz koniec).

\section{ZAKOŃCZENIE}

Powróćmy na koniec do definicji nagłówka, a właściwie do jego założonych funkcji. Jak wspominał S. Gajda, tytuł ma nazywać, informować i oddziaływać. $\mathrm{W}$ obrazie igrzysk zawartym $\mathrm{w}$ analizowanych nagłówkach widać dokonujące się w tym zakresie zmiany. O ile tytuły dotyczące igrzysk w Calgary i w Seulu rzeczywiście przede wszystkim informowały o wydarzeniach sportowych, o tyle w nagłówkach związanych z Rio de Janeiro występuje znacznie więcej ekspresji, elementu sensacji itp. Powodem tego jest ogólna tendencja do tabloidyzacji prasy. Ogromna popularność takich gazet jak „Super Express” czy „Fakt” powoduje, że nawet dziennikarze „Przeglądu Sportowego” zaczynają sięgać po „tabloidalny” repertuar środków. Agnieszka Morzy w tekście Sport w tabloidzie zadała zna-

${ }^{13}$ W. Kajtoch, W świecie tabloidowych nagłówków. Ich retoryka oraz tworzony przez nie obraz rzeczywistości, „Oblicza Komunikacji”, nr 4, 2011, s. 130. 
mienne pytanie: „Ile sportu pozostało w sporcie?"'14. Autorka zwróciła uwagę na bardzo istotną kwestię, jaką jest we współczesnym sporcie nie tyle kult ciała, ile określonego wizerunku. Badaczka pisze m.in.: „Pamiętajmy, że zainteresowanie sponsorów zależy nie tylko od wyników sportowych, lecz także od popularności samych sportowców. A ta budowana jest dziś w dużej mierze przez tabloidy, które dzięki przyjętej konwencji moga pozwolić sobie na zdecydowanie więcej niż tzw. media jakościowe." ${ }^{15}$ Te ostatnie są zdaniem A. Morzy dowodem na profesjonalizację prasy, przejmują ciężar merytorycznych analiz i poświęcone są wyłącznie sportowi. Tymczasem zaprezentowane nagłówki pokazują, że granica między oboma typami mediów zaciera się coraz bardziej ${ }^{16}$.

Jaki jest zatem obraz igrzysk zamknięty w nagłówkach? Z pewnością dynamiczny, tzn. zmieniający się wraz z rozwojem mediów. Zmiana sposobu postrzegania sportowców - traktowanie ich jak celebrytów - rzutuje na charakter doniesień prasowych. A skoro nagłówek ma przyciągnąć odbiorcę, musi być intrygujący, perswazyjny, niekoniecznie merytoryczny. Na pytanie, na ile jest to wpływ zmian w sporcie jako takim, a na ile kształtowanie specyficznego medialnego obrazu sportu, nie ma dobrej odpowiedzi. Sport i media to naczynia połączone, które dziś nie byłyby w stanie funkcjonować bez siebie.

\section{BIBLIOGRAFIA:}

Bereś S., Problematyka komunikatywności i metaforyczności nagłówków prasowych na przykładzie „, Słowa Polskiego”, „Wrocławski Rocznik Prasoznawczy”, 1974.

Encyklopedia wiedzy o prasie, red. J. Maślanka, Wrocław 1976.

Gajda S., O tytułach tekstów. Wprowadzenie do problematyki, „Zeszyty Naukowe WSP w Opolu, Filologia Polska", t. XXIV, 1985.

Gajda S., Społeczne determinacje nazw własnych tekstów (tytułów), „Socjolingwistyka”, nr 6, 1987.

Kajtoch W., Językowy obraz świata i człowieka w prasie młodzieżowej i alternatywnej, Kraków 2008, t. 1-2.

Kajtoch W., W świecie tabloidowych nagłówków. Ich retoryka oraz tworzony przez nie obraz rzeczywistości, „Oblicza Komunikacji”, nr 4, 2011.

Morzy A., Sport w tabloidzie, w: Sport w mediach, red. M. Jarosz, P. Drzewiecki, P. Płatek, Warszawa 2013.

Pałuszyńska E., Nagłówki w „,Gazecie Wyborczej” (ekspresywna leksyka, frazematyka, metaforyka), Łódź 2006.

Pisarek W., Nowa retoryka dziennikarska, Kraków 2002.

Pisarek W., Poznać prasę po nagłówkach!, Kraków 1967.

14 A. Morzy, Sport w tabloidzie, w: Sport w mediach, red. M. Jarosz, P. Drzewiecki, P. Płatek, Warszawa 2013, s. 398.

15 Ibidem, s. 399

16 Świadczyć może o tym eksperyment, podczas którego studenci mieli przypisać nagłówek do odpowiedniej gazety. Nie znaleźli oni w nagłówkach niczego, co pozwoliłoby im na jednoznaczne uznanie tytułu za właściwy dla danego typu prasy. 
Słownik terminologii medialnej, red. W. Pisarek, Kraków 2006.

Ślawska M., Tytut - najmniejszy tekst prasowy, „Rocznik Prasoznawczy”, t. II, 2008.

Wojtak M., Gatunki prasowe, Lublin 2004.

Żydek-Bednarczuk U., Wprowadzenie do lingwistycznej analizy tekstu, Kraków 2005.

\section{Streszczenie}

Artykuł gromadzi nagłówki z trzech gazet: ogólnotematycznej „Gazety Wyborczej”, specjalistycznego „Przeglądu Sportowego” oraz tabloidalnego „Super Expressu” zapowiadające artykuły dotyczące występów Polaków na wybranych igrzyskach olimpijskich z lat 1988-2016. Ich analiza pozwoliła na wyciągnięcie dwóch podstawowych wniosków - wzrasta zainteresowanie sportem, o czym świadczy dużo większa liczba artykułów poświęcony tej tematyce, jednak w dużej mierze jest to zainteresowanie wydarzeniem ujmowanym jako show, a nie w kategoriach czysto sportowych. Obraz igrzysk w mediach jest dynamiczny, zmierzający ku powszechnej tabloidyzacji.

Słowa kluczowe: igrzyska olimpijskie, nagłówek, tabloid.

\section{OLYMPIC GAMES IN NEWSPAPER HEADLINES}

\section{Sum mary}

The article presents newspaper headlines of articles discussing the participation of Polish athletes in Olympic games in the 1988-2016 period. The headlines were extracted from 3 sources: a general daily "Gazeta Wyborcza", a specialized sports daily "Przegląd Sportowy" and a tabloid "Super Express". The analysis allowed for two main conclusions: the interest in sports is on the rise (which is expressed by the increasing number of articles being devoted to the topic); however, the Olympics are to a large extend depicted as a show, not as a sports event. The image of the Olympic games in the media is dynamic and increasingly tabloidlike.

Keywords: Olympic Games, headline, tabloid. 